Journal of Clinical Investigation

Vol. 43, No. 7, 1964

\title{
Studies on Iron Absorption. Intestinal Regulatory Mechanisms *
}

\author{
Munsey S. Wheby, $\dagger$ LeeRoy G. Jones, $\$$ and William H. Crosby \\ (From the Departments of Gastroenterology and Hematology, Walter Reed Army Institute of \\ Research, Washington, $D . C$.)
}

Recent studies (1-3) have indicated that gastrointestinal absorption of iron is a more complicated process than was initially postulated $(4,5)$. For example, several investigators have proposed as the result of studies in rats $(2,3)$, dogs $(6)$, and humans (7) that iron absorption involves at least 2 steps : 1) mucosal uptake of iron from the intestinal lumen and 2) transfer of iron from mucosal cells to plasma. Other evidence has been presented indicating that these steps are distinct, sequential processes (2). In addition, later work (3) has suggested that the second step, mucosal transfer, has two components: 1) a rapid transport mechanism which, within 2 hours after dosing, transfers up to $80 \%$ of the iron ultimately transferred to plasma, and 2) a much slower process which transfers the remainder over the subsequent 12 to 20 hours. It has also been shown that small intestinal mucosal cells ${ }^{1}$ can take up and temporarily hold more iron than is ultimately transferred to plasma, resulting in loss of some of this iron as the mucosal cells are sloughed at the end of their life span $(1,3)$.

In view of the complex nature of the over-all process of iron absorption, our studies were made during the early, rapid phase in an attempt to gain a clearer concept of mucosal handling of iron. The experiments were designed to evaluate the rate of mucosal uptake and transfer of iron to plasma, the site of maximal absorption, and the

* Submitted for publication September 19, 1963 ; accepted March 2, 1964.

Presented in part at the American Federation for Clinical Research, April 29, 1962.

† Present address: United States Tropical Research Medical Laboratory, San Juan, Puerto Rico.

\$ Present address: United States Medical Research and Development Command, Office of the Surgeon General, Washington, D. C.

1 In this paper the term "mucosal cells" refers to epithelial cells of the intestinal mucosa. influence of varying body iron stores on these processes.

\section{Methods}

Male albino rats of the WRCF strain, ${ }^{2}$ weighing 325 to $350 \mathrm{~g}$, were used. The principles of laboratory animal care as promulgated by the National Society for Medical Research were observed. The basic methods used to determine iron absorption including operative technique for making duodenal loops, preparation of $\mathrm{Fe}^{\text {so }}$-labeled test dose of iron, and radioisotope counting procedures utilizing a small animal whole body counter have been previously described in detail $(3,8,9)$. In essence the procedure involved injecting a known amount of $\mathrm{Fe}^{50}$-labeled ferrous iron into an operatively prepared closed loop of gut in anesthetized but otherwise intact rats. Formation of the closed loops was accomplished by applying a proximal and a distal ligature around the serosal surface of the segment of intestine to be studied. Care was taken not to occlude observable vessels. The color of the loops remained normal throughout the study; several loops removed 1 hour after formation showed no abnormal histologic changes by light microscopy. After a preselected time interval, absorption was terminated by removing the closed gut segment in toto from carcass. The segment was then opened, washed to remove unabsorbed iron, and weighed, and its radioactive iron content and that of the carcass were counted separately. Since the gut and carcass were counted separately, it was possible to measure 1) total amount of iron absorbed from intestinal lumen (total radioiron content of gut segment plus carcass), to be referred to as "mucosal uptake," and 2) amount of iron transferred from mucosal cells to carcass (carcass radioiron content), to be referred to as "mucosal transfer." By using the known specific activity of the test dose, results were usually converted to, and expressed as, micrograms of iron absorbed per loop of gut.

To vary body iron stores, rats were randomized into 3 groups. One group ( $\mathrm{FeD})$ was made iron deficient by repeated bleeding and feeding a casein base, synthetic, iron-poor diet; the last bleeding was 2 weeks before study. A second group ( $F e L$ ) was loaded with 50 $\mathrm{mg}$ of iron dextran intramuscularly 3 weeks before

2 The Walter Reed Carworth Farm strain is derived from the Wistar strain and, as supplied, is pathogen free. 


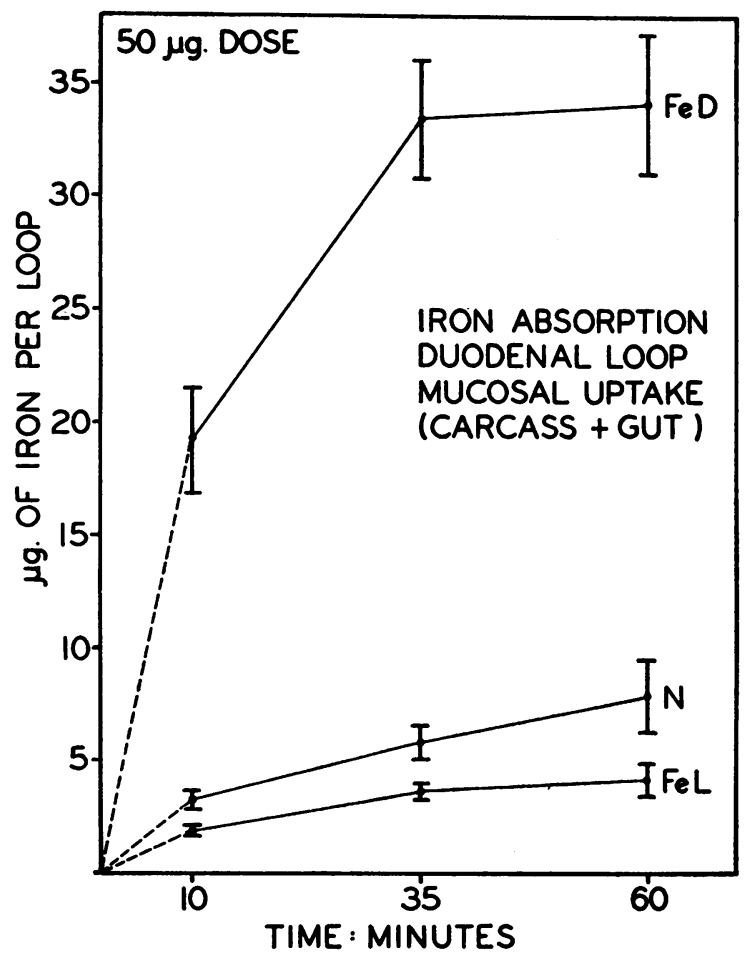

Fig. 1. RATE of MUCOSAL UPTAKe OF IRON FRom LUMEN OF DUODENAL LOOPS AFTER A SINGLE 50- $\mu$ G DOSE OF RAdioIron. $\mathrm{FeD}=$ iron-deficient, $\mathrm{N}=$ normal, and $\mathrm{FeL}$ $=$ iron-loaded rats. The brackets indicate $1 \mathrm{SE}$.

study. This amount of iron was well tolerated. A third group $(N)$ was untreated and like the second group was maintained on regular rat chow. For all experiments, food was removed from the cages 8 to 10 hours before study.

\section{Experimental Procedures and Results}

Effect of common bile duct ligation on the absorption of radioiron. Since bile accumulated in the closed duodenal loops during the absorption period, the effect of common bile duct ligation on iron absorption was determined by preparing duodenal loops in the usual manner in 8 normal rats. Immediately preceding preparation of the loop in 4 of the rats, the bile duct was ligated just above its entry into the duodenum. Fifty $\mu \mathrm{g}$ of labeled iron was injected into each loop, and an absorption time of 60 minutes was allowed.

Results. Ligation of the common bile duct did not affect iron absorption significantly as shown in Table I. As a result of this finding, the bile duct was not ligated for any of the other studies.
TABLE I

Effect of common bile duct ligation on radioiron absorption

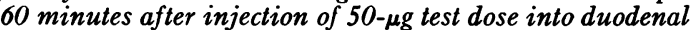
loops in normal rats

\begin{tabular}{lcc}
\hline \hline & $\begin{array}{c}\text { Mucosal uptake } \\
\text { from lumen* }\end{array}$ & $\begin{array}{c}\text { Mucosal transfer } \\
\text { to carcass* }\end{array}$ \\
\hline \multirow{2}{*}{ Control } & \multicolumn{2}{c}{$\mu g \mathrm{Fe} /$ loop } \\
Bile duct ligated & $9.75 \pm 0.7 \dagger$ & $4.72 \pm 0.92$ \\
& $9.89 \pm 0.99 \dagger$ & $4.64 \pm 1.7$
\end{tabular}

$*$ Mean \pm SE.

$\dagger$ Difference not significant at $10 \%$ level with $t$ test (10).

Onset of iron absorption. An attempt was made to determine how rapidly iron absorption would begin after the dose was administered. A duodenal loop was prepared in each of 4 iron-deficient rats, and $2.5 \mu \mathrm{g}$ of $\mathrm{Fe}^{59}$-labeled ferrous iron was injected. Fifteen to 26 seconds after injection the loops were removed to terminate absorption, and the carcass and gut were counted in the usual manner.

Results. The onset of iron absorption was extremely rapid. Radioiron was detected in the carcass of iron-deficient rats as early as $15 \mathrm{sec}$ onds after the test dose was put into the duode-

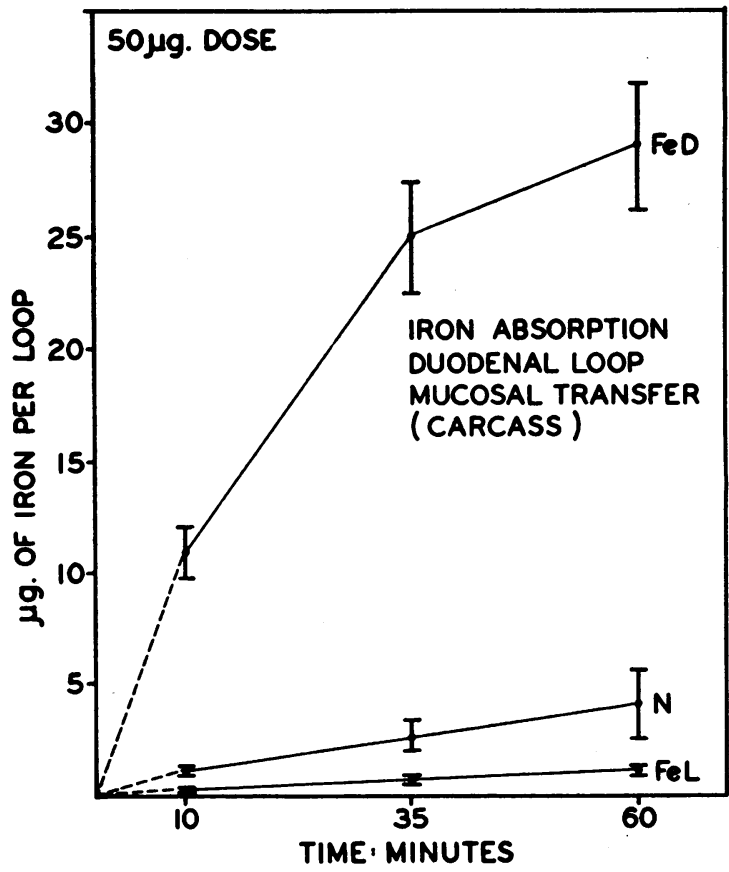

Fig. 2. RATE OF MUCOSAL TRANSFER OF IRON TO CARCASS AFTER A SINGLE 50- $\mu$ G DOSE OF RADIOIRON. The brackets indicate $1 \mathrm{SE}$. 


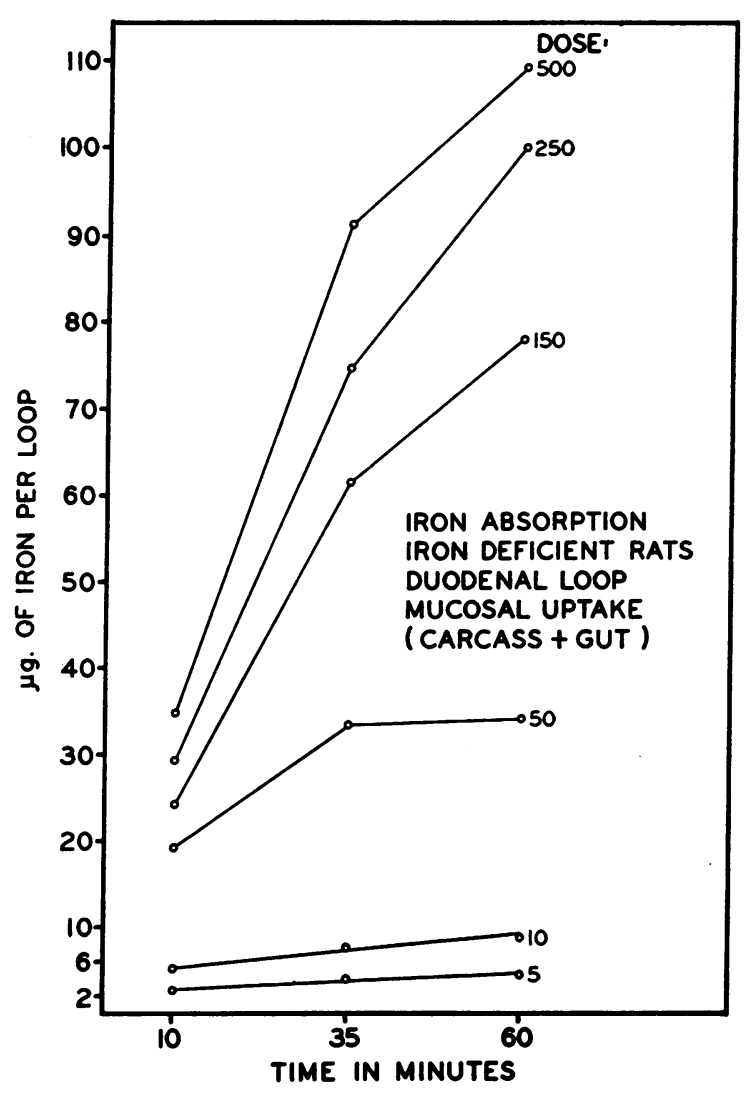

Fig. 3. Rate of MUCOSAL UPtake of IRON FROM LUMEN OF DUODENAL LOOPS IN IRON-DEFICIENT RATS AFTER A SINGLE DOSE OF VARYING AMOUNTS OF RADIOIRON.

num. With only 26 seconds or less for absorption, mucosal uptake varied from 1.2 to $4.1 \%$ of the $2.5-\mu \mathrm{g}$ dose, and mucosal transfer was 0.46 to $2.5 \%$.

Rate of iron absorption and the effect of varying body iron stores. Studies on rate of iron absorption and the influence of body iron stores were done by preparing loops of duodenum in groups $\mathrm{N}, \mathrm{FeL}$, and $\mathrm{FeD}$. Mucosal uptake and mucosal transfer to carcass were determined 10 , 35 , and 60 minutes after injecting a dose ranging from 5 to $500 \mu \mathrm{g}$ of $\mathrm{Fe}^{59}$-labeled carrier iron into groups $\mathrm{N}$ and $\mathrm{FeD}$ and from 5 to $125 \mu \mathrm{g}$ in group FeL. Four to 7 rats from each group were studied to obtain a mean absorption for each time and each dose; a total of 260 experiments were performed.

Results. Figures 1 and 2 show a comparison of the rate of absorption from duodenal loops in normal $(\mathrm{N})$, iron-deficient $(\mathrm{FeD})$, and iron- loaded rats (FeL) after a dose of $50 \mu \mathrm{g}$ of labeled iron. Figure 1 shows the comparison of mucosal uptake of iron from intestinal lumen, i.e., the sum of the iron transferred to carcass plus the iron retained by the washed gut segment. At each time, group $\mathrm{FeD}$ mucosal uptake was approximately 9 times greater than group $\mathrm{FeL}$ and 5 times greater than group $\mathrm{N}$. The differences observed between the means for groups $\mathrm{FeL}$ and $\mathrm{N}$ were slight but statistically significant; values for $\mathrm{p}$ obtained with the $t$ test $(10)$ were $<0.05,<0.05$, and $<0.1$ for 10,35 , and 60 minutes, respectively. Shown also in Figure 1 is the cessation of mucosal uptake after 35 minutes in group $\mathrm{FeD}$. That this was due principally to a decreasing and thus limiting amount of iron in the lumen is shown in Figure 3. When larger amounts of iron $(150$ to $500 \mu \mathrm{g}$ ) were used, mucosal uptake continued after 35 minutes although at a somewhat decreased rate.

Figure 2 illustrates the comparison of mucosal transfer of iron to carcass for groups $\mathrm{N}, \mathrm{FeD}$, and FeL. A more marked difference between groups was found with this comparison than when mucosal uptake was compared (Figure 1). At each time, transfer by group $\mathrm{FeD}$ was approximately 30 to 40 times greater than group $\mathrm{FeL}$ and 9 times greater than group $\mathrm{N}$. The differ-

TABLE II

Mucosal uptake and mucosal transfer to carcass from duodenal loops by 35 minutes for each test dose in rats with varying body iron stores

\begin{tabular}{|c|c|c|c|c|}
\hline Group & Dosage & $\begin{array}{l}\text { Mucosal } \\
\text { uptake* }\end{array}$ & $\underset{\text { trar }}{\mathrm{Mu}}$ & $\begin{array}{l}\text { icosal } \\
\text { nsfer* }\end{array}$ \\
\hline \multirow[b]{2}{*}{ Normal (N) } & $\mu g / F e$ & \multicolumn{3}{|c|}{$\mu g \mathrm{Fe} /$ loop } \\
\hline & $\begin{array}{r}5 \\
10 \\
50 \\
150 \\
250 \\
500\end{array}$ & $\begin{array}{c}2.9 \pm 0.79 \\
3.3 \pm 0.4 \\
5.8 \pm 0.75 \\
13.6 \pm 2.2 \\
17.7 \pm 1.8 \\
34.8 \pm 8.3\end{array}$ & $\begin{array}{r}1.9 \\
2.1 \\
2.7 \\
4.0 \\
6.8 \\
10.7\end{array}$ & $\begin{array}{l} \pm 0.65 \\
\pm 0.4 \\
\pm 0.7 \\
\pm 1.5 \\
\pm 1.6 \\
\pm 2.7\end{array}$ \\
\hline Iron loaded (FeL) & $\begin{array}{r}5 \\
10 \\
50 \\
125\end{array}$ & $\begin{array}{c}1.6 \pm .25 \\
2.5 \pm 1.0 \\
3.6 \pm 0.38 \\
13.6 \pm 3.0\end{array}$ & $\begin{array}{l}0.35 \\
0.5 \\
0.67 \\
2.8\end{array}$ & $\begin{array}{l} \pm 0.17 \\
\pm 0.09 \\
\pm 0.28 \\
\pm 0.28\end{array}$ \\
\hline Iron deficient $(\mathrm{FeD})$ & $\begin{array}{r}5 \\
10 \\
50 \\
150 \\
250 \\
500\end{array}$ & $\begin{array}{l}3.9 \pm 0.14 \\
7.5 \pm 0.38 \\
33.4 \pm 2.7 \\
61.6 \pm 3.9 \\
74.7 \pm 8 \\
91.4 \pm 7.4\end{array}$ & $\begin{array}{r}3.6 \\
6.9 \\
25.0 \\
34.3 \\
41.7 \\
39.6\end{array}$ & $\begin{array}{l} \pm 0.13 \\
\pm 0.32 \\
\pm 2.4 \\
\pm 4.0 \\
\pm 1.4 \\
\pm 2.2\end{array}$ \\
\hline
\end{tabular}

$*$ Mean $\pm \mathrm{SE}$ 
IRON ABSORPTION
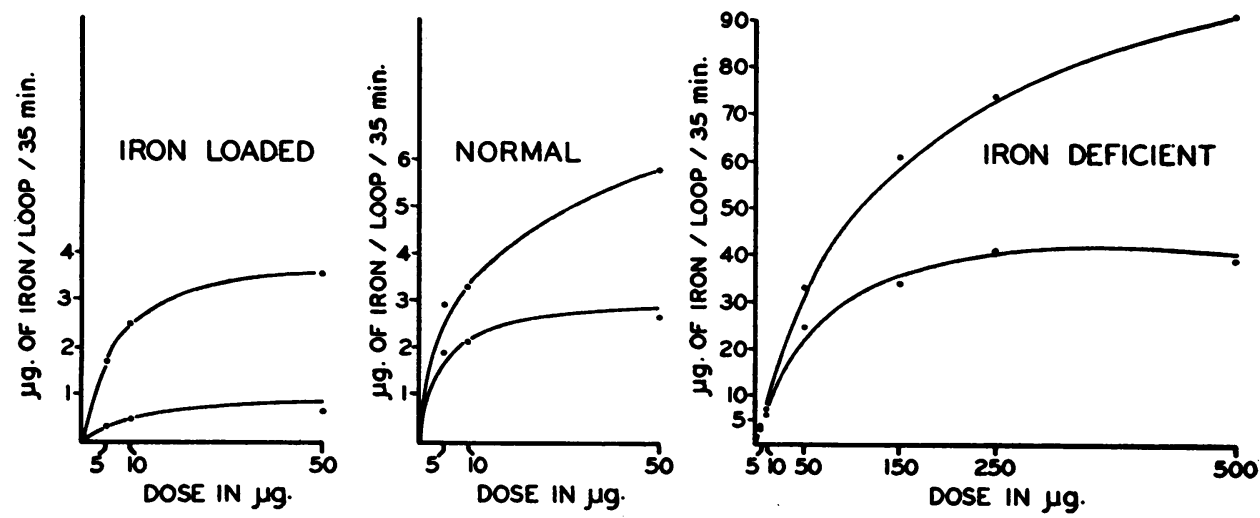

Fig. 4. Rate of mucosal uptake of iRon from LUMEN (UPPER CURVes) and Rate of MUCOSAL TRANSFER TO CARCASS (LOWER CURVES) AFTER A SINGLE DOSE OF VARYING AMOUNTS OF RADIOIRON. Status of body iron stores is indicated. Note difference in units of coordinates for iron-deficient group.

ences between the means for groups $\mathrm{FeL}$ and $\mathrm{N}$ were small but significant; values for $p$ were $<0.01,<0.05$, and $<0.1$ for 10,35 , and 60 minutes, respectively.

Table II contains the values obtained for mucosal uptake and mucosal transfer at 35 minutes for each animal group and test dose of iron. A portion of these data is shown in Figure 4. In all 3 groups, as the dose was increased, both mu-

TABLE III

Relationship between mucosal uptake and mucosal transfer to carcass for duodenal loops at each test dose and absorption time in rats with varying body iron stores

\begin{tabular}{|c|c|c|c|c|}
\hline & \multirow[b]{2}{*}{ Dose } & \multicolumn{3}{|c|}{$\begin{array}{l}\text { Ratio mucosal transfer: } \\
\text { mucosal uptake } \\
\text { Absorption time }\end{array}$} \\
\hline & & $\begin{array}{l}10 \\
\text { minutes }\end{array}$ & $\begin{array}{c}35 \\
\text { minutes }\end{array}$ & $\begin{array}{c}\mathbf{6 0} \\
\text { minutes }\end{array}$ \\
\hline Normal (N) & $\begin{array}{r}\mu g F e \\
5 \\
10 \\
50 \\
150 \\
250 \\
500\end{array}$ & $\begin{array}{l}0.47 \\
0.41 \\
0.35 \\
0.18 \\
0.25 \\
0.15\end{array}$ & $\begin{array}{l}0.66 \\
0.63 \\
0.46 \\
0.30 \\
0.39 \\
0.31\end{array}$ & $\begin{array}{l}0.59 \\
0.63 \\
0.52 \\
0.34 \\
0.49 \\
0.14\end{array}$ \\
\hline Iron loaded $(\mathrm{FeL})$ & $\begin{array}{r}5 \\
10 \\
50 \\
125\end{array}$ & $\begin{array}{l}0.16 \\
0.18 \\
0.13 \\
0.19\end{array}$ & $\begin{array}{l}0.20 \\
0.20 \\
0.18 \\
0.20\end{array}$ & $\begin{array}{l}0.42 \\
0.41 \\
0.26 \\
0.20\end{array}$ \\
\hline Iron deficient $(\mathrm{FeD})$ & $\begin{array}{r}5 \\
10 \\
50 \\
150 \\
250 \\
500\end{array}$ & $\begin{array}{l}0.83 \\
0.81 \\
0.57 \\
0.41 \\
0.36 \\
0.32\end{array}$ & $\begin{array}{l}0.91 \\
0.92 \\
0.75 \\
0.56 \\
0.56 \\
0.43\end{array}$ & $\begin{array}{l}0.92 \\
0.90 \\
0.85 \\
0.69 \\
0.58 \\
0.45\end{array}$ \\
\hline
\end{tabular}

cosal uptake and transfer increased in a curvilinear fashion, and both appeared to be approaching a maximal transport rate. When these data were plotted in the double reciprocal manner of Lineweaver and Burk, a linear relationship characteristic of enzymatic processes (11) was observed (Figure 5). In group $\mathrm{FeD}$, this relationship was maintained to the $500-\mu \mathrm{g}$ dose, indicating that under these conditions the absorptive mechanism in iron-deficient rats has kinetics consistent with an enzymatic process. In groups $\mathrm{FeL}$ and $\mathrm{N}$, the linear relationship between the reciprocal of the absorption rate and the reciprocal of the dose no longer held when the dose exceeded $50 \mu \mathrm{g}$ of iron. Above this dose there was a greater increase in mucosal uptake and mucosal transfer than if the previous relationship had been maintained. The new relationship in group $\mathrm{N}$, shown in an arithmetic plot in Figure 6, indicates that as the test dose of iron was increased from 50 to $500 \mu \mathrm{g}$, both mucosal uptake and mucosal transfer increased linearly. Both lines in Figure 6 are least squares regression lines (10). They show that a statistically significant ${ }^{3}(p<0.01)$ linear relationship exists between dose of iron and both mucosal uptake and mucosal transfer. This type of relationship is very suggestive of passive diffusion of iron across the intestinal mucosa. These results indicate that in group $\mathrm{N}$,

3 Tested by analysis of variance (10). 

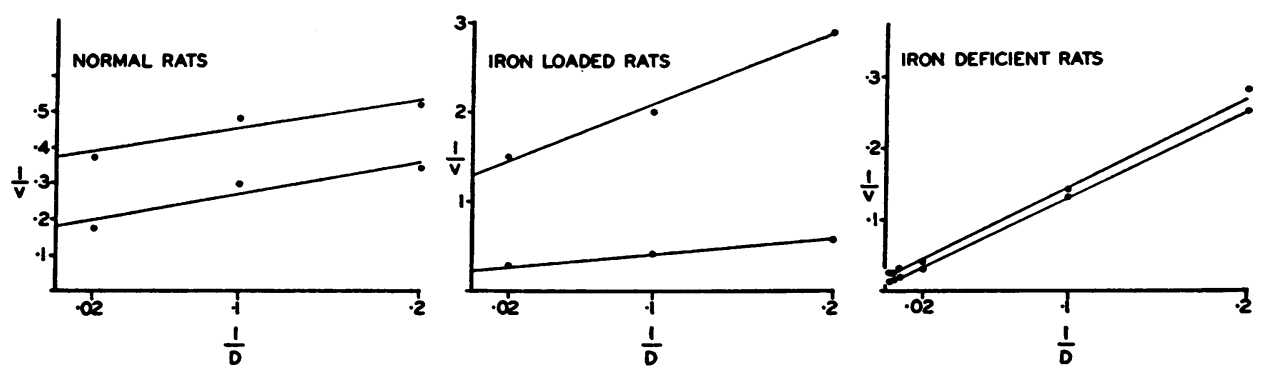

Fig. 5. Plot of the Reciprocal of MUCOSAL UPtake (LOWER LINE) AND MUCOSAL tRANSFER (UPPER LINE) AT 35 MINUTES AGAINST THE RECIPROCAL OF THE DOSE OF IRON USED. Status of body iron stores is indicated. Note difference in units for $1 / \mathrm{v}$ in each plot.

with small doses of iron ( 5 to $50 \mu \mathrm{g}$ ), the predominant absorptive mechanism has kinetics consistent with an enzymatic process, but with larger doses $(50$ to $500 \mu \mathrm{g}$ ), another process with the kinetics of passive diffusion supervenes.

The comparisons shown in Figure 4 clearly illustrate that the rate of mucosal uptake of iron from lumen exceeded the rate of mucosal transfer of iron to carcass. This difference in rate was reflected by the persistence of a ratio of less than 1 for the relationship of mucosal transfer: mucosal uptake. This ratio is shown in Table III for each group at each point of time and test dose. In general in all groups, as the test dose was raised, the difference in rates was increased as indicated by the ratio. As the absorption time was increased from 10 to 60 minutes, the ratio indicates that the difference between the rates was decreasing. In group $\mathrm{FeD}$ the ratio was close to 1 until test doses of $50 \mu \mathrm{g}$ or greater were used, indicating little difference in rate with the lower doses. In groups $\mathrm{N}$ and $\mathrm{FeL}$ a difference in rate was apparent even with the $5-\mu \mathrm{g}$ dose, as indicated by the low ratios of 0.59 in group $\mathrm{N}$ and 0.42 in group $\mathrm{FeL}$ at 60 minutes. This rather marked difference in rates meant that more iron was entering mucosal cells than could be transferred to carcass even by 60 minutes.

Effect of prefeeding iron. The effect of prefeeding iron on subsequent duodenal mucosal uptake and mucosal transfer was evaluated. Thirty normal rats were randomized into 3 groups of 10 each. Each group was divided equally into a control and prefed subgroup. After a period of 10 hours without food, one group was prefed 1 hour, another group 6 hours, and the third group 24 hours preceding the absorption study. The prefeeding consisted of $250 \mu \mathrm{g}$ of nonradioactive

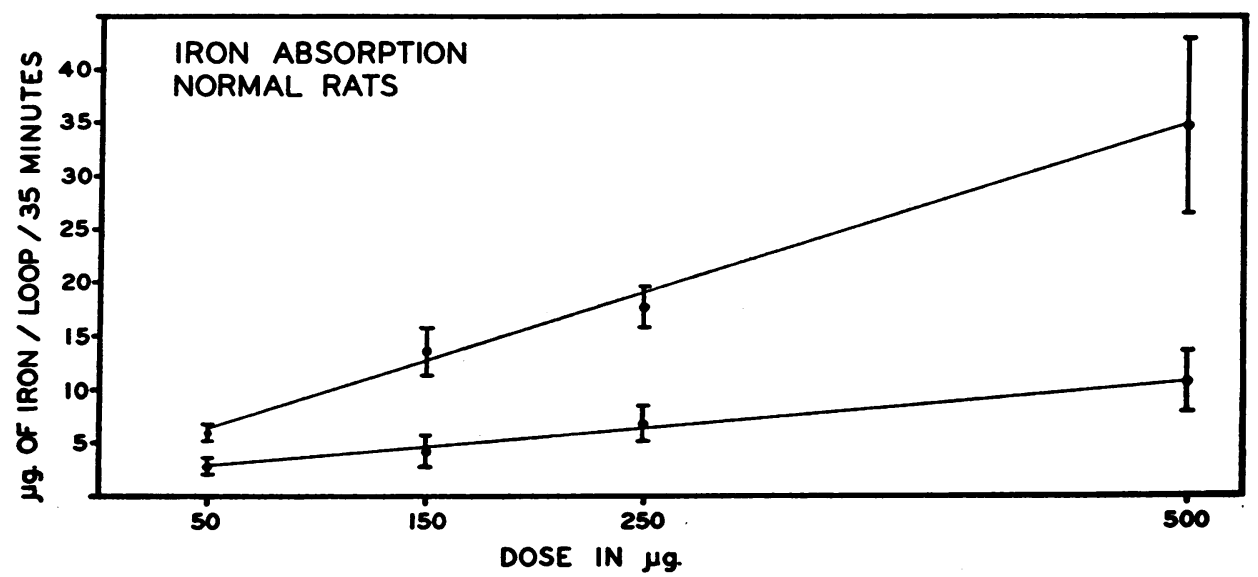

Fig. 6. RATE OF MUCOSAL UPTAKE OF IRON FROM LUMEN (UPPER LINE) AND RATE OF MUCOSAL TRANSFER to CARCASS (LOWER LINE) AFTER A SINGLE DOSE OF VARYING AMOUNTS OF RADIOIRON IN NORMAL RATS. The brackets indicate $1 \mathrm{SE}$. 
TABLE IV

Effect of prefeeding iron on subsequent radioiron absorption 30 minutes after injection of 12.5- $\mu \mathrm{g}$ test dose into duodenal loops in normal rats

\begin{tabular}{|c|c|c|c|c|c|c|}
\hline \multirow{2}{*}{$\begin{array}{l}\text { Time after } \\
\text { prefeeding } \\
\text { until study }\end{array}$} & \multicolumn{2}{|c|}{ Mucosal uptake from lumen* } & \multirow[b]{2}{*}{$\mathrm{p}$} & \multicolumn{2}{|c|}{ Mucosal transfer to carcass* } & \multirow[b]{2}{*}{ p } \\
\hline & Control & Prefed & & Control & Prefed & \\
\hline & \multicolumn{2}{|c|}{$\mu g \mathrm{Fe} /$ loop } & & \multicolumn{2}{|c|}{$\mu g \mathrm{Fe} / \mathrm{loop}$} & \\
\hline $\begin{array}{c}1 \text { hour } \\
6 \text { hours } \\
24 \text { hours }\end{array}$ & $\begin{array}{l}1.54 \pm 0.08 \\
1.37 \pm 0.25 \\
1.35 \pm 0.19\end{array}$ & $\begin{array}{l}1.01 \pm 0.19 \\
1.51 \pm 0.12 \\
1.73 \pm 0.28\end{array}$ & $\begin{array}{l}<0.05 \\
\text { NSt } \\
\text { NSt }\end{array}$ & $\begin{array}{l}0.96 \pm 0.1 \\
0.68 \pm 0.2 \\
0.66 \pm 0.16\end{array}$ & $\begin{array}{l}0.38 \pm 0.18 \\
0.63 \pm 0.1 \\
0.63 \pm 0.11\end{array}$ & $\begin{array}{l}<0.05 \\
\text { NS } \\
\text { NSt }\end{array}$ \\
\hline
\end{tabular}

$*$ Mean \pm SE.

$\dagger$ Not significant at $10 \%$ level with $t$ test (10).

ferrous iron as ferrous sulfate given intragastrically by gavage. Each control subgroup was treated in the same manner except that $0.9 \%$ saline was given instead of iron. Only water was allowed from the time of prefeeding until study. For the determination of mucosal uptake and transfer, two changes were made in the usual technique for preparing and dosing duodenal loops. First, a polyethylene cannula was placed in the distal end of the loop, and second, before the test dose of radioiron was injected, the loop was gently flushed with $5 \mathrm{ml}$ of warm saline to remove any iron remaining in the lumen. Control subgroups were treated similarly. The test dose was $12.5 \mu \mathrm{g}$ of $\mathrm{Fe}^{59}$-labeled ferrous iron, and the absorption time was 30 minutes.

Results. The effect of prefeeding iron on subsequent mucosal uptake and mucosal transfer is shown in Table IV. Giving $250 \mu \mathrm{g}$ of "cold"

TABLE $V$

Comparison of radioiron absorption 35 minutes after injection

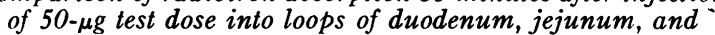
ileum in rats with varying body iron stores

\begin{tabular}{|c|c|c|c|}
\hline & $\begin{array}{l}\text { Mucosal up- } \\
\text { take from } \\
\text { lumen* (a) }\end{array}$ & $\begin{array}{l}\text { Mucosal trans- } \\
\text { fer to } \\
\text { carcass* (b) }\end{array}$ & $\mathrm{b}: \mathrm{a}$ \\
\hline & \multicolumn{2}{|c|}{$\mu g \mathrm{Fe} / \mathrm{loop}$} & \\
\hline \multicolumn{4}{|l|}{ Iron loaded (FeL) } \\
\hline Duodenum & $3.82 \pm 0.31$ & $0.88 \pm 0.6$ & 0.23 \\
\hline Proximal jejunum & $4.44 \pm 0.36$ & $0.22 \pm 0.1$ & 0.05 \\
\hline Distal ileum & $2.09 \pm 0.6$ & $0.08 \pm 0.07$ & 0.04 \\
\hline \multicolumn{4}{|l|}{ Normal (N) } \\
\hline Duodenum & $6.85 \pm 1.26$ & $3.04 \pm 0.35$ & 0.44 \\
\hline Proximal jejunum & $2.9 \pm 2.4$ & $0.20 \pm 0.16$ & 0.07 \\
\hline Distal ileum & $1.73 \pm 0.53$ & $0.07 \pm 0.06$ & 0.04 \\
\hline \multicolumn{4}{|l|}{ Iron deficient (FeD) } \\
\hline Duodenum & $28.00 \pm 0.04$ & $20.01 \pm 0.8$ & 0.72 \\
\hline Proximal jejunum & $10.63 \pm 1.23$ & $3.76 \pm 0.73$ & 0.35 \\
\hline Distal ileum & $3.88 \pm 0.23$ & $0.05 \pm 0.06$ & 0.01 \\
\hline
\end{tabular}

$*$ Mean $\pm \mathrm{SE}$. ferrous iron to normal rats 1 hour before the absorption study with radioiron depressed mucosal uptake $34 \%$ and mucosal transfer $60 \%$. Six hours after feeding, the depressive effect was no longer noted.

Site of iron absorption and the effect of varying body iron stores. Mucosal uptake and mucosal transfer of radioiron to carcass by loops of duodenum, jejunum, ileum, colon, and stomach were compared in groups $\mathrm{N}, \mathrm{FeL}$, and $\mathrm{FeD}$. The duodenal loops measured approximately 4 to $5 \mathrm{~cm}$ in length. The other intestinal sites were studied with the same operative technique for preparing loops and for injecting the labeled iron. Proximal jejunal loops approximately $7.5 \mathrm{~cm}$ in length were made. Distal ileal loops were prepared by placing a distal ligature just above the ileocecal valve and an upper ligature approximately $12 \mathrm{~cm}$ proximal. The different lengths were used to compensate for variation in surface area (12). Colonic loops approximately $10 \mathrm{~cm}$ in length were made just distal to the cecum. Since ileum and colon usually contained feces, the test sites were washed clean with a $2-\mathrm{ml}$ injection of warm $0.9 \%$ saline before the distal suture was applied and the test dose injected. For preparing the closed stomach one ligature was placed around the esophagus just below the diaphragm and another at the pylorus. The test dose of iron was injected into the pyloric end of the stomach as the ligature placed there was drawn tight. The test dose in all of these studies was $50 \mu \mathrm{g}$ of $\mathrm{Fe}^{59}$-labeled ferrous iron. In comparing absorption from duodenum, jejunum, and ileum, 4 rats from each group were used for studying each site. The absorption time allowed was 35 minutes. For the stomach and colon experiments, 3 rats from each group were used for each site, and the absorption time 
was 1 hour. All results were expressed as micrograms of iron absorbed per loop.

Results. A comparison of mucosal uptake and mucosal transfer by loops of duodenum, proximal jejunum, and distal ileum in rats with varying body iron stores is shown in Table $\mathrm{V}$, and a similar comparison of stomach and colon is shown in Table VI. Values are listed for mucosal uptake, mucosal transfer, and the ratio of mucosal transfer to mucosal uptake. Table $\mathrm{V}$ shows that with one exception ( $\mathrm{FeL}$, mucosal uptake) both mucosal uptake and mucosal transfer were greatest in duodenum, less in jejunum, and least in ileum. The difference was more marked for mucosal transfer, which showed a rather abrupt decrease below the duodenum. This was reflected by the low ratio of mucosal transfer to mucosal uptake for jejunum and ileum. A similar low ratio was found for stomach and colon (Table VI).

The effect of varying body iron stores was most evident in duodenum, where iron deficiency $(\mathrm{FeD})$ affected an increase, and iron loading ( $\mathrm{FeL}$ ) a decrease, in both mucosal uptake and mucosal transfer of iron as compared to normal animals $(\mathrm{N})$. The most marked effect was on mucosal transfer (Table V). The iron-deficiency state resulted in a change in the proximal jejunum, where an increase in both steps was found, and as a consequence, absorption was approximately as efficient as in normal duodenum. Mucosal transfer to carcass was the same for jejunum in groups $\mathrm{N}$ and $\mathrm{FeL}$, and similarly, there was no difference in the 3 groups when ileum (Table V) or stomach and colon (Table VI) were compared. Except for a slight increase in mucosal uptake by colon in group FeL, mucosal uptake and mucosal transfer by stomach and colon were the same regardless of body iron stores (Table VI).

Effect of bypassing duodenum. In an effort to determine what effect bypassing duodenum would have on total amount of iron absorbed, the following two studies were done. Instead of preparing closed loops, when the abdomen was opened, the test dose of iron was injected directly into the intestinal lumen by puncture with a 27 gauge needle. Careful checks revealed no leakage of radioactivity. Puncture for duodenal injection was made at the pylorus, for jejunal injection aproximately 4 to $6 \mathrm{~cm}$ distal to the py-
TABLE VI

\begin{tabular}{|c|c|c|c|}
\hline & $\begin{array}{l}\text { Mucosal up- } \\
\text { take from } \\
\text { lumen* (a) }\end{array}$ & $\begin{array}{l}\text { Mucosal trans- } \\
\text { fer to car- } \\
\text { cass* (b) }\end{array}$ & $\mathrm{b}: \mathrm{a}$ \\
\hline \multicolumn{4}{|c|}{$\mu g \mathrm{Fe} / \mathrm{loop}$} \\
\hline \multicolumn{4}{|c|}{ Iron loaded (FeL) } \\
\hline $\begin{array}{l}\text { Stomach } \\
\text { Colon }\end{array}$ & $\begin{array}{l}1.6 \pm 0.2 \\
3.2 \pm 0.56\end{array}$ & $\begin{array}{l}0.15 \pm 0.04 \\
0.11 \pm 0.01\end{array}$ & $\begin{array}{l}0.09 \\
0.03\end{array}$ \\
\hline \multicolumn{4}{|l|}{ Normal (N) } \\
\hline $\begin{array}{l}\text { Stomach } \\
\text { Colon }\end{array}$ & $\begin{array}{l}1.3 \pm 0.2 \\
1.5 \pm 0.2\end{array}$ & $\begin{array}{l}0.12 \pm 0.02 \\
0.14 \pm 0.02\end{array}$ & $\begin{array}{l}0.09 \\
0.09\end{array}$ \\
\hline \multicolumn{4}{|c|}{ Iron deficient (FeD) } \\
\hline $\begin{array}{l}\text { Stomach } \\
\text { Colon }\end{array}$ & $\begin{array}{l}2.4 \pm 0.46 \\
1.7 \pm 0.4\end{array}$ & $\begin{array}{l}0.12 \pm 0.02 \\
0.16 \pm 0.02\end{array}$ & $\begin{array}{l}0.05 \\
0.09\end{array}$ \\
\hline
\end{tabular}

$*$ Mean \pm SE.

lorus, and for ileal injection approximately $15 \mathrm{~cm}$ proximal to the ileocecal valve. After the dose had been injected, the abdominal wall was closed, and the rats were allowed to recover.

In the first study involving 8 normal rats, $25 \mu \mathrm{g}$ of labeled iron was put into duodenum in 4 , and into jejunum in the other 4 . When the rats were killed, the entire gastrointestinal tract was removed, opened, washed to remove unabsorbed iron, and counted separately from carcass as previously described (3).

In the second study $12.5 \mu \mathrm{g}$ of labeled iron was injected into each of 15 normal rats, 5 into duodenum, 5 into jejunum, and 5 into ileum. Final absorption was determined by counting the whole rat 8 days later, at a time when all unabsorbed iron had been excreted (9).

Results. The effect of bypassing duodenum on iron absorption is shown in Tables VII and VIII. As would be expected from the results of the loop studies, bypassing the duodenum decreased mu-

TABLE VII

Comparison of radioiron absorption 3 hours after direct injection of $25-\mu \mathrm{g}$ test dose into intestinal lumen of normal rats

\begin{tabular}{|c|c|c|c|c|}
\hline \multirow[b]{2}{*}{ Site of injection } & \multirow{2}{*}{$\begin{array}{c}\text { Mucosal } \\
\text { uptake } \\
\text { from } \\
\text { lumen* (a) }\end{array}$} & \multirow{2}{*}{$\begin{array}{c}\text { Mucosal } \\
\text { transfer to } \\
\text { carcass* (b) }\end{array}$} & \multicolumn{2}{|c|}{ Decrease } \\
\hline & & & $\mathbf{a}$ & $\mathbf{b}$ \\
\hline & $\begin{array}{c}\mu g \mathrm{Fe} \\
12.3 \pm 2.3\end{array}$ & $\begin{array}{c}\mu g F e \\
8.4 \pm 2.1\end{array}$ & $\%$ & $\%$ \\
\hline Proximal jejunum & $3.9 \pm 1.3$ & $1.3 \pm 0.5$ & 68 & 85 \\
\hline
\end{tabular}

$*$ Mean $\pm \mathrm{SE}$. 
TABLE VIII

Comparison of radioiron absorption 8 days after direct injection of 12.5- $\mu \mathrm{g}$ test dose into intestinal lumen of normal rats

\begin{tabular}{lcc}
\hline \multicolumn{1}{c}{ Site of injection } & $\begin{array}{c}\text { Total } \\
\text { absorption* }\end{array}$ & $\begin{array}{c}\text { Decrease } \\
\text { in ab- } \\
\text { sorption }\end{array}$ \\
\hline $\begin{array}{l}\text { Duodenum } \\
\text { Proximal jejunum }\end{array}$ & $8.8^{\mu \mathrm{Fe}} \pm 0.5$ & $\%$ \\
Distal ileum & $3.2 \pm 0.7$ & 64 \\
& $0.12 \pm 0.02$ & 98 \\
\hline
\end{tabular}

${ }^{*}$ Mean $\pm \mathrm{SE}$.

cosal transfer to a greater extent than mucosal uptake. In the 3-hour absorption study mucosal uptake was decreased $68 \%$ and mucosal transfer $85 \%$ (Table VII).

Table VIII shows the marked effect of bypassing the proximal segments of small intestine on over-all iron absorption. Bypassing only 4 to 6 $\mathrm{cm}$ of proximal small intestine (duodenum) decreased absorption $64 \%$. This result represents a conservative estimate of the true effect. Some reflux into duodenum probably occurred when the test dose was injected into the jejunum. When all but approximately $15 \mathrm{~cm}$ of distal small intestine was bypassed, absorption was decreased $98 \%$ compared to that found after injection of the dose into duodenum. This suggested that distal ileum and colon contributed very little to total iron absorption.

\section{Discussion}

Our data support those previously reported $(2,13,14)$ which indicate that iron is absorbed by an active transport mechanism comprised of at least two steps: 1) mucosal uptake of iron from the intestinal lumen and 2) mucosal transfer of iron to carcass. Differences were observed between the two steps. For example, mucosal transfer was restricted more specifically to the proximal small intestine; the rate of mucosal transfer was less than the rate of mucosal uptake and was thus more limiting to over-all absorption of iron. There were also similarities, in that both steps varied inversely with changes in body iron stores and both were decreased by prefeeding iron; however, mucosal transfer was influenced by these factors to a greater extent than mucosal uptake. These observations are in close agreement with those described by Manis and
Schachter $(2,14)$. Our studies show that during the early, rapid phase of iron absorption, when up to $80 \%$ of the total amount absorbed was accomplished $(3,7)$, the kinetics of the absorptive mechanism were consistent with those shown by enzymatic processes. This mechanism has previously been shown not to be dependent on availability of unsaturated transferrin to maintain a favorable gradient across mucosal cells $(8,15)$. In iron-deficient animals, the kinetics consistent with an enzyme-mediated process applied up to the largest dose of iron used $(500 \mu \mathrm{g})$, where attainment of a maximal rate of transport appeared imminent. This is further suggestive evidence supporting an active transport mechanism (16). Since in normal and iron-loaded rats similar kinetics were also found, the same type of absorptive mechanism was apparently operative as in irondeficient rats, although with a greatly decreased capacity. In contrast to iron-deficient animals, however, when the test dose of iron exceeded 50 $\mu \mathrm{g}$, the kinetics of the absorptive mechanism changed to those consistent with passive diffusion. We interpret this change to mean that the regulating effect of a limited mucosal transport and storage capacity for iron ("mucosal block") was exceeded to such an extent that another process, passive diffusion of iron across the intestinal mucosa, began to occur. Whether diffusion occurred or not appeared to depend on the relationship between dose of iron given and transport capacity of the mucosa. Although this phenomenon was not observed in iron-deficient animals, it very likely would have occurred if greater amounts of iron had been given to exceed further the transport capacity. From our studies with duodenal loops, we cannot predict accurately what dose of iron given orally, or intragastrically, would be required to achieve a "critical" level for diffusion to occur. Factors avoided by the use of closed intestinal loops, as for example, gastric emptying and intestinal transit time, would affect significantly both the amount of iron reaching an intestinal site and also the time during which the intestinal site is in contact with the iron. Gitlin and Cruchaud (17), in studies of over-all iron absorption in mice, found a change from a nonlinear to a linear relationship when doses greater than approximately $100 \mu \mathrm{g}$ of iron were given. Their interpretation of the significance of this 
change is similar to ours, i.e., when a critical amount of iron is exceeded, a change in the predominant mechanism of absorption occurs.

In addition to the rapidly acting transport mechanism, previous studies have shown evidence for a second, slower absorptive pathway $(3,7$, 18) involving a process putting iron into a more stable, slowly released form. In our studies, iron seemingly became available for intracellular storage as a result of the rate of mucosal uptake exceeding the rate of mucosal transfer. The amount of iron put into the slowly released form is important, since we have found previously in normal $(1,3)$ and iron-loaded rats (3) that a relatively large portion of the amount temporarily stored was not subsequently transferred to carcass but was lost with the sloughed mucosal cells.

The present experiments indicate that mucosal cells possess an absorptive mechanism which is responsive to body iron requirements and which within limits is capable of regulating iron absorption. In addition to this, another finding should be emphasized, i.e., the rather marked restriction of the most effective iron absorbing area to the proximal $6 \mathrm{~cm}$ of small intestine in normal rats. Iron-deficient rats showed an increase in the area of effective iron absorbing mucosa. The proximal jejunum, even after a brief period of iron deficiency, came to resemble the normal duodenum in its effectiveness of iron absorption. These adaptive changes in rate and area are very important in determining total amount absorbed from a single dose of iron, since the time during which iron is available for absorption is limited by formation of nonabsorbable complexes (6) and by movement of iron distally in the intestinal lumen.

A basic problem yet to be solved is the manner in which these changes are mediated in response to body iron requirements. Recent work from this laboratory has postulated $(1,19)$ that the concentration of plasma iron or the iron binding capacity might influence or determine the intrinsic iron absorptive capacity built into newly formed cells. Whether control of iron absorption is truly an intrinsic property of mucosal cells may be established more definitely when biochemical characterization of the mucosal transport and storage mechanisms is accomplished.

\section{Summary}

Studies on rate and site of iron absorption were performed during the early, rapid phase of iron absorption by the use of closed intestinal loops in anesthetized but otherwise intact rats with varying body iron stores. With the use of $\mathrm{Fe}^{59}$ and whole body counting, it was possible to determine total iron absorbed from intestinal lumen and iron transferred to carcass during accurately timed absorption periods. The findings suggest that iron is absorbed by an active transport mechanism comprised of at least two steps : 1) mucosal uptake of iron from lumen and 2) mucosal transfer of iron to carcass. Both steps varied inversely with the state of body iron stores. Compared to mucosal uptake, mucosal transfer was more restricted to duodenum, more affected by changes in body iron stores and prefeeding iron, and regardless of body iron stores showed a lower rate. In addition to the rapid transport system, mucosal cells have a mechanism for putting iron into temporary storage. The transport and storage capacity appeared to regulate the amount absorbed into carcass until a critical dose of iron was given to normal and iron-loaded rats. When this dose was exceeded, a process suggestive of passive diffusion of iron was seen.

The site studies confirm the duodenum as the most efficient site of iron absorption and emphasize the rather marked decrease in absorption found when the test dose of iron was injected only 4 to 6 $\mathrm{cm}$ distal to the pylorus. Extension into proximal jejunum of the more effective area for iron absorption was observed in iron-deficient animals.

\section{References}

1. Conrad, M. E., and W. H. Crosby. Intestinal mucosal mechanisms controlling iron absorption. Blood 1963, 22, 406.

2. Manis, J. G., and D. Schachter. Active transport of iron by intestine: features of the two-step mechanism. Amer. J. Physiol. 1962, 203, 73.

3. Wheby, M. S., and W. H. Crosby. The gastrointestinal tract and iron absorption. Blood 1963, 22, 416.

4. Hahn, P. F., W. F. Bale, J. F. Ross, W. M. Balfour, and G. H. Whipple. Radioactive iron absorption by gastro-intestinal tract. Influence of anemia, anoxia, and antecedent feeding. Distribution in growing dogs. J. exp. Med. 1943, 78, 169. 
5. Granick, S. Ferritin: IX. Increase in protein apoferritin in gastrointestinal mucosa as a direct response to iron feeding. The function of ferritin in the regulation of iron absorption. J. biol. Chem. 1946, 164, 737.

6. Duthie, H. L., C. F. Code, and C. A. Owen, Jr. Absorption of iron from the small bowel of dogs. Gastroenterology 1962, 42, 599.

7. Hallberg, L., and L. Sölvell. Absorption of a single dose of iron in man. Acta med. scand. 1960 (suppl. 358), 19.

8. Wheby, M. S., and L. G. Jones. Role of transferrin in iron absorption. J. clin. Invest. 1963, 42, 1007.

9. Forrester, R. H., M. E. Conrad, and W. H. Crosby. Measurement of total body iron $^{50}$ in animals using whole-body liquid scintillation detectors. Proc. Soc. exp. Biol. (N. Y.) 1962, 111, 115.

10. Batson, H. C. An Introduction to Medical Statistics. Minneapolis, Burgess, 1957.

11. Neilands, J. B., and P. K. Stumpf. Outlines of Enzyme Chemistry. New York, John Wiley, 1955, pp. 75-76.
12. Fisher, R. B., and D. S. Parsons. Gradient of mucosal surface area in the small intestine of the rat. J. Anat. (Lond.) 1950, 84, 272.

13. Dowdle, E. B., D. Schachter, and H. Schenker. Active transport of $\mathrm{Fe}^{5 \theta}$ by everted segments of rat duodenum. Amer. J. Physiol. 1960, 198, 609.

14. Manis, J. G., and D. Schachter. Active transport of iron by intestine: effects of oral iron and pregnancy. Amer. J. Physiol. 1962, 203, 81.

15. Pollack, S., S. P. Balcerzak, and W. H. Crosby. Transferrin and the absorption of iron. Blood 1963, 21, 33.

16. Taggart, J. V. Mechanisms of renal tubular transport. Amer. J. Med. 1958, 24, 774.

17. Gitlin, D., and A. Cruchaud. On the kinetics of iron absorption in mice. J. clin. Invest. 1962, 41, 344.

18. Brown, E. B. The absorption of iron. Amer. J. clin. Nutr. 1963, 12, 205.

19. Crosby, W. H. The control of iron balance by the intestinal mucosa. Blood 1963, 22, 441. 